\title{
Assessment of knowledge, attitude, and practice towards COVID 19 pandemic prevention among undergraduate student of Bule Hora University, southern Ethiopia
}

Lechisa Asefa ( $\square$ lechisa123@gmail.com)

Bule Hora University

\section{Research Article}

Keywords: knowledge, Attitudes, Practice, COVID-19

Posted Date: June 16th, 2021

DOl: https://doi.org/10.21203/rs.3.rs-628626/v1

License: (9) This work is licensed under a Creative Commons Attribution 4.0 International License.

Read Full License 
Assessment of knowledge, attitude, and practice towards COVID 19 pandemic prevention among undergraduate student of Bule Hora University, southern Ethiopia

Lechisa Asefa ${ }^{1}$, Hailu lema ${ }^{2}$, Muzeyin Ibrahim ${ }^{3}$, Zakariya Usmael ${ }^{3}$, wako Golicha ${ }^{3}$, Chala daba $^{2}$ 


\section{Abstract}

Aim: The aim of this study was to assess the knowledge, attitudes, and practice of Bule Hora university undergraduate student towards COVID-19 pandemic prevention, October 2020

\section{Methods and materials}

The KAP of Bule Hora University undergraduate students were assessed using a cross-sectional study design. As a data collection tool, a structured questionnaire was used. Epi-Data version 4.5 was used to enter the data, and SPSS version 25 was used to analyze it. The Knowledge, Attitude and practice (KAP) of student was analyzed by using likert scale analysis and multinomial logistic regression analysis were used to analysis the association between dependent and independent variables

The results: -From total study participants, $75 \%$ and $69.8 \%$ of them have adequate knowledge and positive attitude on COVID-19 symptoms, prevention and control measures. 92\% of respondents Known as COVID-19 can be transmitted directly through contact with infected surfaces. Half of the participants have adequate practice to prevent and control COVID-19 disease. The multinomial logistic regression show that residence $(P=0.005$, AOR $=2$. 48(1.2965.803)) and income $(P=0.004, A O R=2.633(1.49-5.350))$ has an association with Knowledge and attitude of students.

Conclusion: - the majority of undergraduate students of the Bule Hora University had well knowledge and more than half of them had a positive attitude about COVID-19 pandemic prevention and control. However, they have low practice to prevent COVI-19 pandemic

Keywords: knowledge, Attitudes, Practice, COVID-19 


\section{Introduction}

Coronavirus disease (COVID-19) is a respiratory illness caused by severe acute respiratory syndrome coronavirus 2 (SARS-CoV-2), which was first emerged in China in late December 2019 (Qian et al., 2020). These viruses are transmitted from infected to healthy person via respiratory droplets, touching contaminated surfaces or objects and then touching their mouth, nose, or possibly their eyes (Kumar et al., 2020). the most commonly reported symptoms are fever, dry cough, fatigue, shortness of breath, sore throat, and chest pain, gastrointestinal, muscle ache, and headache/ confusion with the incubation period from 1 to 14 days (WHO, 2020b). Those people who show severe cases were almost older people and underlying certain conditions like cardiovascular disease, hypertension and diabetes ( $\mathrm{Z}$ and JM, 2020)

Globally, as of September 28, 2020, more than 32.7 million cases of COVID-19 were confirmed and 991,000 deaths were reported by the World Health Organization (WHO, 2020c). The death rate of this coronaviruses is alarming from time to time all over the world. In Africa, over 1.2 million cases were confirmed and 26,475 deaths were reported (WHO, 2020a). As explained by Global health experts and African governments coronaviruses might cause more than 2 million deaths in sub-Saharan Africa if action is not taken (Walker et al., 2020). According to the WHO report from September 23 to 29/2020, the incidence rate of COVID-19 cases was increased by $2 \%$ and the death rate was decreased by $20 \%$ during the previous reporting period (23 - 29 September 2020). These coronavirus outbreak is not only affecting the community but also losing the life of many healthcare professionals and janitors in all the country including Ethiopia.

Besides, the outbreak of this coronaviruses has been damaging the economy of the country. This unprecedented outbreak was massive destruction of the global economy by affecting global supply chain integration and restriction of export and import, travel as well. International Monetary Fund (IMF) also explained and predicts that the gross domestic product (GDP) was falling by $3 \%$ due to coronaviruses outbreak. As African Economic Growth, explains and predicts that the Economic Commission of Africa (ECA) will more likely to decrease by 1.8 percent in the best-case scenario and a contraction of 2.6 percent if the worst case happens (ECA, 2020). 
Even though Ethiopia reported the first cases of COVID 19 on 13 March 2020, until October 9, 2020, over 81,797 confirmed cases and 1262 deaths were reported. From the Africa region, Ethiopia is the second highest reporting case of COVID-19 following in South Africa in the past seven days (23 - 29 September 2020) (WHO, 2020a). To limit the transmission of this pandemic disease and save the life of human being, nations across the globe, including Ethiopia have taken different preventive measures such as movement restriction, stay at home (limit travel to and from the country), the closure of schools and university, social distance, hand washing with soap and sanitizers, using face and mouth mask and other social services. However, the number of cases is still increasing (Dong et al., 2020; Zettler et al., 2020)

It is obvious that if the university accepts the students, the number of COVID-19 cases will rise because the students may come from the area where the disease is prevalent. It is critical to have sufficient knowledge, attitudes, and practice about basic hygiene principles and modes of disease transmission, as well as COVID-19 prevention and control measures, in order to reduce install effective control measures. Furthermore, improving students' knowledge, attitudes, and practice of COVID-19 prevention and control methods will contribute significantly to limiting the outbreak's spread. However, a study of COVID-19 pandemic prevention and control knowledge, attitudes, and practice among Blue Hora University students is not assessed. Thus, the main aim of this is to assess the knowledge, attitudes and practice towards COVID-19 pandemic prevention and control among the students of the Bule Hora University

\section{Methods and material}

\subsection{Study setting}

The study was conducted at Bule Hora University in October 2020. Bule Hora University was one university among higher education in Ethiopia and it's located in southern Ethiopia, Oromia, and West Guji zone. Currently, Bule Hora University has 164 programs, 89 undergraduates, 69 Masters and 6 PhDs; and 10,542 regular, 6578 extension, totaling 17,120 students (16,368 undergraduate, 752 postgraduate); with 1153 academic staff and 3239 admin staff, under eight colleges, one school and one institute. It's located at 467km from Addis Ababa. It's situated at a latitude and longitude of $5^{\circ} 34^{\prime} 59.99^{\prime \prime} \mathrm{N}$ and $38^{\circ} 19^{\prime} 60.00^{\prime \prime} \mathrm{E}$ and the annual temperature range between $53{ }^{0} \mathrm{~F}$ to $89{ }^{0} \mathrm{~F}$. 


\subsection{Study design}

Cross-sectional study design was conducted to assess KAP of Bule Hora University graduate class students

\subsection{Sample size determination}

The single population proportion formula was used to calculate the sample size. Based on a review of previous studies on KAP of various community members on Covid-19, the proportion of Debre Berhan University students who believe that children and young adults do not need to take precautions to avoid becoming infected with the COVID-19 virus is low 41.5 percent of the total was used(Asmare, Debre and Orcid, 2020). Final the total calculated sample size was 410.

\subsection{Sampling techniques}

Random sampling technique was used to select study individuals.

\subsection{Data collection tools}

Previous studies, WHO training material for the detection, prevention, response, and control of COVID-19 and center for disease control (CDC) guidelines for clinical and community management of COVID-19 were used to create structured questioners.

\subsection{Methods of Measurement (Scoring)}

All questions of the questionnaire were close-ended questionnaire consisted of knowledge, attitude, and practice domains

(1) Knowledge Domain. -it consisted of 19 multiple-choice questions and Knowledge questions were scored either " 1 " or " 0 for the correct and incorrect response, respectively." total knowledge score for each study participant was computed, and the possible score could range from 0 to 19 . The overall knowledge score was computed by summation of all the individual study participants' total knowledge scores. Finally, the mean score was calculated by dividing the overall knowledge score by the number of study participants. Knowledge scores below and above or equal to the mean score were assigned for inadequate and adequate knowledge, respectively(Deress et al., 2018)

(2) Attitude Domain. It comprised of 7 Likert items. A three-point Likert scale of measurement was used to represent scores, as such "Disagree," "Neutral," and "Agree," and were given numerical scores 1, 2, 3, respectively. For negatively phrased statements, scores were reversely coded during the data entry period as 3,2 , and 1 . The composite score for each study participant 
was computed which could range from 7 to 21 . Overall attitude score was calculated by adding all the study participants' attitude scores, and the mean score was computed by dividing the overall attitude score by the number of study participants. Finally, attitude scores below the mean and above or equal to the mean score were assigned for unfavorable and favorable attitude, respectively(Deress et al., 2018).

(3) Practice Domain. Eleven multiple-choice practice questions were used, and they were dichotomized by giving "1"or " 0 " point for correct and incorrect responses, respectively. Likewise, knowledge and attitude questions, for practice questions total individual and overall practice scores were calculated. Then mean score was calculated by dividing the overall practice score by the number of study participants. Practice scores below the mean and above or equal to the mean score were assigned for inadequate and adequate practice, respectively(Deress et al., 2018).

\subsection{Data analysis procedures}

The raw quantitative data were coded and entered into Epi-Data version 4.5, and then the data were exported to SPSS version 25 for analysis. The KAP statuses of the students were analyzed by Likert scale of measurement. Binary logistic regression analyses were used to identify factors associated with KAP. Variables with a p-value $<0.025$ during bivariable analysis were used in our multivariable analyses to control for confounding effects. Adjusted odds ratios (AORs) and their $95 \%$ confidence intervals (CIs) were used to quantify the associations between variables and KAP. Variables with $\mathrm{p}$-value $=0.05$ after multivariable analysis were considered significantly associated with the outcome variable. 


\section{Results}

\subsection{Socio-demographic characteristics of Bule Hora University Graduating Class}

The results of this study revealed that the majority (67.8\%) of the respondents were male and the aged 20-24 (94.9\%). Regarding marital status, almost (98.5\%) of the study participant was single and the main source of information was from social media (Facebook and Television). The detailed results are explained in table 1 below

Table 1: Socio-demographic characteristics of Blue Bora University, graduating class, October 2020

\begin{tabular}{|c|c|c|c|c|}
\hline S.no & \multicolumn{2}{|l|}{ Variable } & frequency & Percent (\%) \\
\hline \multirow[t]{2}{*}{1} & \multirow[t]{2}{*}{ Sex } & Male & 260 & 67.8 \\
\hline & & Female & 123 & 32.2 \\
\hline \multirow[t]{2}{*}{2} & \multirow[t]{2}{*}{ Age group } & $20-24$ & 363 & 94.9 \\
\hline & & $\geq 25$ & 20 & 5.1 \\
\hline \multirow[t]{2}{*}{3} & \multirow[t]{2}{*}{ Marital status } & Single & 377 & 98.5 \\
\hline & & Married & 6 & 1.5 \\
\hline \multirow[t]{3}{*}{4} & \multirow[t]{3}{*}{ Monthly pocket money } & $<200$ & 286 & 74.7 \\
\hline & & $200-400$ & 79 & 20.6 \\
\hline & & $>400$ & 18 & 4.7 \\
\hline \multirow[t]{4}{*}{5} & \multirow[t]{4}{*}{ Religion } & Protestant & 94 & 24.6 \\
\hline & & Orthodox & 171 & 44.6 \\
\hline & & Muslim & 109 & 28.4 \\
\hline & & Waqefata & 9 & 2.3 \\
\hline \multirow[t]{2}{*}{6} & \multirow[t]{2}{*}{ Residence } & Rural & 269 & 70.2 \\
\hline & & Urban & 115 & 29.8 \\
\hline \multirow[t]{4}{*}{7} & \multirow[t]{4}{*}{ Source of information } & Google & 145 & 12.12 \\
\hline & & Social media (Fb, Tv and etc.) & 383 & 32 \\
\hline & & Government bodies & 312 & 26.1 \\
\hline & & Family/ friends & 356 & 29.7 \\
\hline
\end{tabular}




\subsection{Knowledge of Students to prevent and control COVID-19}

75 percent of the total study participants have adequate knowledge of COVID-19 symptoms, prevention, and control measures. COVID-19 can be transmitted directly through contact with infected surfaces, according to 92 percent of respondents, but only 41.4 and $57.8 \%$ of respondents were aware that diarrhea is a symptom of COVID-19.and as it is necessary for children and young adults to take measures to prevent the infection by the COVID-19 virus respectively.

Table 2 shows the Knowledge concerning COVID-19 among graduate classes of the Bule Hora University, Ethiopia Oct 2020

\begin{tabular}{|c|c|c|c|c|c|}
\hline S. & \multirow[t]{3}{*}{ Knowledge questions } & \multicolumn{4}{|c|}{ Responses } \\
\hline no & & \multicolumn{2}{|c|}{ Yes } & \multicolumn{2}{|l|}{ No } \\
\hline & & Free & Per. (\%) & Free & Per. \\
\hline 1. & Fever is a symptom of COVID-19? & 321 & 83.7 & 62 & 16.3 \\
\hline 2. & Dry Cough is a symptom of COVID-19? & 336 & 87.6 & 47 & 12.4 \\
\hline 3. & The sore throat is a symptom of COVID-19? & 304 & 79.3 & 79 & 20.7 \\
\hline 4. & Bodily pain is a symptom of COVID- $19 ?$ & 288 & 75.1 & 95 & 24.9 \\
\hline 5. & Diarrhea or constipation is a symptom of COVID-19? & 159 & 41.4 & 224 & 58.6 \\
\hline 6. & Headache is a symptom of COVID-19? & 318 & 83.1 & 65 & 16.9 \\
\hline 7. & Elder's people are the disease more at risk for COVID-19? & 352 & 92.0 & 31 & 8 \\
\hline 8. & Chronic illnesses, and are obese are more likely to be severe case? & 256 & 66.9 & 127 & 33.1 \\
\hline 9. & $\begin{array}{l}\text { Persons with COVID- } 2019 \text { cannot infect the virus to others when a fever is } \\
\text { not present? }\end{array}$ & 161 & 42.0 & 222 & 58 \\
\hline 10. & $\begin{array}{l}\text { The COVID-19 virus spreads via respiratory droplets of an infected } \\
\text { individual? }\end{array}$ & 300 & 78.4 & 83 & 21.6 \\
\hline 11. & COVID-19 is prevented by using a face mask? & 326 & 85.2 & 57 & 14.8 \\
\hline 12. & For proper wearing, the surgical mask should cover Nose, mouth, and chin? & 349 & 91.1 & 34 & 8.9 \\
\hline 13. & COVID-19 is prevented by using hand washing with soap frequently? & 337 & 87.9 & 46 & 12.1 \\
\hline 14. & $\begin{array}{l}\text { It is not necessary for children and young adults take measures to prevent } \\
\text { the infection by the COVID-19 virus? }\end{array}$ & 165 & 43.2 & 218 & 56.8 \\
\hline 15. & $\begin{array}{l}\text { To prevent the infection by COVID-19, individuals should avoid going to } \\
\text { crowded places? }\end{array}$ & 314 & 82.0 & 69 & 18 \\
\hline 16. & $\begin{array}{l}\text { Isolation and treatment of people who are infected with the COVID-19 } \\
\text { virus are effective ways to reduce the spread of the virus? }\end{array}$ & 334 & 87.3 & 49 & 12.7 \\
\hline 17. & $\begin{array}{l}\text { The disease can be transmitted directly through contact with infected } \\
\text { surfaces? }\end{array}$ & 352 & 92.0 & 31 & 8 \\
\hline 18. & $\begin{array}{l}\text { The disease can be transmitted directly through contact with infected } \\
\text { individuals (handshaking, hugging, kissing)? }\end{array}$ & 366 & 95.5 & 17 & 4.5 \\
\hline 19. & The disease is more dangerous in pregnant women? & 247 & 64.5 & 140 & 36.5 \\
\hline
\end{tabular}




\subsection{The attitude of Students to prevent and control COVID-19}

$267(69.8 \%)$ of the total respondents have a favorable attitude toward COVID-19 prevention and control measures. COVID-19 will be successfully controlled, according to all of the respondents, and COVID-19 can be prevented by washing hands with soap, according to the majority of them (89.1\%). The detailed results are explained in table 3 below.

Table 3 shows the attitude concerning COVID-19 among graduate classes of the Bule Hora University, Ethiopia Oct 2020.

\begin{tabular}{|c|c|c|c|c|c|c|c|}
\hline \multirow{3}{*}{$\begin{array}{l}\text { S. } \\
\text { no }\end{array}$} & \multirow[t]{3}{*}{ Attitude questions } & \multicolumn{6}{|c|}{ Responses } \\
\hline & & \multicolumn{2}{|c|}{ Agree } & \multicolumn{2}{|c|}{ Disagree } & \multicolumn{2}{|c|}{ neutral } \\
\hline & & Fre & Per. & Free & Per. & Free & Per. \\
\hline 1. & Do you agree that COVID-19 is prevented by using face mask? & 305 & 79.6 & 59 & 15.4 & 19 & 5.0 \\
\hline 2. & $\begin{array}{l}\text { Do you agree that COVID-19 is prevented by hand washing with } \\
\text { soap? }\end{array}$ & 341 & 89.1 & 27 & 7.1 & 15 & 3.8 \\
\hline 3. & $\begin{array}{l}\text { Do you agree that COVID-19 is prevented by keeping } 1 \mathrm{~m} \text { social } \\
\text { distance? }\end{array}$ & 287 & 74.9 & 82 & 21.3 & 15 & 3.8 \\
\hline 4. & Do you agree that COVID-19 is fatal? & 279 & 72.8 & 42 & 10.9 & 62 & 16.3 \\
\hline 5. & $\begin{array}{l}\text { During the outbreak, do you think that eating well-cooked and } \\
\text { safely handled meat is safe }\end{array}$ & 287 & 74.9 & 53 & 13.9 & 43 & 11.2 \\
\hline 6. & $\begin{array}{l}\text { Do you agree early detection of COVID-19 can improve } \\
\text { treatment and outcome? }\end{array}$ & 297 & 77.5 & 54 & 14.2 & 32 & 8.3 \\
\hline 7. & Do you agree health education can help prevent COVID-19? & 339 & 88.5 & 25 & 6.5 & 19 & 5.0 \\
\hline
\end{tabular}

\footnotetext{
${ }^{1}$ Fre. = frequency

Per. =percent
} 


\subsection{The practice of Students to prevent and control COVID-19}

194 (50.6 percent) of Bule Hora University's graduating class have appropriate practice in preventing and controlling COVID-19 disease. During the COVID-19 epidemic, the majority of pupils (95.9\%) wore personal protective equipment (masks), did not have a phone to call for aid in case of suspicion $(44 \%)$ and did not dispose of worn masks in the trash $(35.6 \%)$.

Table 4 Shows the Practice concerning COVID-19 among graduate classes of the Blue Hare University, Ethiopia October 2020.

\begin{tabular}{|c|c|c|c|c|c|}
\hline \multirow[t]{3}{*}{ S. no } & \multirow[t]{3}{*}{ Practice questions } & \multicolumn{4}{|c|}{ Responses } \\
\hline & & \multicolumn{2}{|l|}{ Yes } & \multicolumn{2}{|l|}{ No } \\
\hline & & Fre. & Per (\%) & Fer. & Per.(\%) \\
\hline 1. & $\begin{array}{l}\text { Did the outbreak of the COVID-19 virus make you increase the } \\
\text { frequency of washing hands? }\end{array}$ & 349 & 91.1 & 34 & 8.9 \\
\hline 2. & $\begin{array}{l}\text { Did the outbreak of the COVID-19 virus do you use personal } \\
\text { protective equipment (e.g. Mask) more often than you used to? }\end{array}$ & 367 & 95.9 & 16 & 4.1 \\
\hline 3. & $\begin{array}{l}\text { Did you carry hand sanitizer with you during the outbreak in } \\
\text { Ethiopia? }\end{array}$ & 321 & 83.7 & 62 & 16.3 \\
\hline 4. & $\begin{array}{l}\text { Did you write down or store in your phone any helpline number to } \\
\text { contact in case you suspected that you or someone you know has the } \\
\text { COVID-19 virus? }\end{array}$ & 213 & 55.6 & 170 & 44.4 \\
\hline 5. & Did you maintain social distance during the outbreak? & 307 & 80.2 & 76 & 19.8 \\
\hline 6. & $\begin{array}{l}\text { Did you cover coughs and sneeze with a tissue / handkerchief during } \\
\text { the outbreak? }\end{array}$ & 318 & 83.1 & 65 & 16.9 \\
\hline 7. & Did you avoid unnecessary travel or outing during the outbreak? & 319 & 83.4 & 64 & 16.6 \\
\hline 8. & Did you dispose used mask in dust bin? & 246 & 64.2 & 137 & 35.8 \\
\hline 9. & Do you wash your hands after sneezing or coughing? & 273 & 71.3 & 110 & 28.7 \\
\hline 10. & Do you touch your face, nose, or mouth with your unclean hands? & 126 & 32.8 & 257 & 67.2 \\
\hline 11. & $\begin{array}{l}\text { In order to prevent contracting and spreading COVID-19 I avoid } \\
\text { handshaking, hugging and kissing }\end{array}$ & 331 & 86.4 & 52 & 13.6 \\
\hline
\end{tabular}

${ }^{2}$ Fre. $=$ Frequency

Per. $=$ percent 


\subsection{Multiple logistic regression analysis}

According to the results of the multiple logistic regression analysis, students who live in the urban are 2.48 times more likely to be knowledgeable than those who live in the rural, and students with a monthly income of more than 400 ETB are 2.633 times more likely to have a good attitude than those who do not.

Table 5shows the multivariate analyses of factor associated with the Knowledge and Attitude of graduate classes of the Blue Hare University,

Ethiopia October 2020

\begin{tabular}{|c|c|c|c|c|c|c|c|c|c|}
\hline \multicolumn{2}{|l|}{ Variables } & \multicolumn{2}{|c|}{ Knowledge } & \multirow[t]{3}{*}{ AOR } & \multirow[t]{3}{*}{ P-value } & \multicolumn{2}{|l|}{ Attitude } & \multirow[t]{3}{*}{ AOR } & \multirow[t]{3}{*}{ P-value } \\
\hline & & \multirow{2}{*}{ Adequate } & \multirow{2}{*}{ Poor } & & & & & & \\
\hline & & & & & & positive & Negative & & \\
\hline Residence & Urban & 85 & 29 & $\begin{array}{l}2.48(1.296- \\
5.803)\end{array}$ & 0.005 & 82 & 32 & $\begin{array}{l}2.58(1.0239 \\
-6.868)\end{array}$ & 0.013 \\
\hline \multirow{2}{*}{$\begin{array}{l}\text { Income } \\
\text { (monthly) }\end{array}$} & $>200$ & 134 & 152 & $2.21(1.23-7.89)$ & \multirow{2}{*}{0.019} & 197 & 89 & & \multirow[t]{2}{*}{0.04} \\
\hline & $\geq 400$ & 11 & 7 & $2.45(1.33-9.1)$ & & 12 & 6 & $\begin{array}{l}2.633(1.49- \\
5.350)\end{array}$ & \\
\hline \multirow{2}{*}{$\begin{array}{l}\text { Marital } \\
\text { status }\end{array}$} & Single & 201 & 176 & \multirow[t]{2}{*}{$1.52(0.01-7.95)$} & \multirow[t]{2}{*}{0.89} & 208 & 170 & \multirow{2}{*}{$\begin{array}{l}1.21(0.14- \\
8.85)\end{array}$} & \multirow[t]{2}{*}{1.01} \\
\hline & Married & 2 & 4 & & & 5 & 1 & & \\
\hline
\end{tabular}

3

\footnotetext{
${ }^{3} \mathrm{AOR}=$ Adjusted odd ration
} 


\section{Discussion}

This study examines undergraduate students at Bule Hora University's knowledge, attitudes, and practices on COVID-19 pandemic prevention and control. As a result, the findings of this study revealed that $75 \%$ of respondents had a solid understanding of COVID-19 pandemic prevention. In contrast to another study, the findings of this one were higher than those of a survey done on college students in Dessie, Amhara area (69.6\%)(Teferi, 2020). The varying degrees of research participants and study time could be a plausible explanation for this study. It was, however, similar to a survey conducted at Debre Berhan University, which found that 73.8 percent of participants (students) had a good understanding of COVID-19(Asmare, Debre and Orcid, 2020). Furthermore, the Bule Hora University graduating class has less knowledge than studies conducted in China (82.3 percent)(Wang et al., 2020). According to (13) regarding COVID-19 pandemic prevention, students in Chinese universities have a good level of understanding due to health education provided to them.

In comparison to research conducted at Debre Brehan University and among college students in Desie city, this student has a better understanding of how the COVID-19 virus can be disseminated by respiratory droplets from infected individuals and how COVID-19 can be prevented by avoiding crowded settings. Furthermore, a cross-sectional survey conducted in Dessie town on COVID 19 knowledge, attitudes, and behavior among college students found that the majority of respondents (82.5\%) believed that regular hand washing with water and soap might prevent the pandemic, which was lower than the current study. This might be due to variation in the study period, which can affect the knowledge of the participant.

According to the findings, $68.9 \%$ of the respondents had a good view on COVID-19 prevention and control. This study's outcome was lower than an online cross-sectional survey conducted in China (73.8\%) and Malaysia (83.1\%), according to another study (Peng et al., 2020)(Azlan et al., 2020). This difference could be related to study time and raising student understanding of the COVID-19 and communication methods. COVID-19 can be prevented by washing hands with soap, according to 89.1 percent of participants, which is greater than a study conducted among Debre Brehane University students (Asmare, Debre and Orcid, 2020). 
The findings of this survey revealed that half of the respondents had good COVID-19 preventive experience. The findings matched those of investigations conducted in the Amhara area and Addis Ababa(Tadesse et al., 2020)(Atkure Defar et al., 2020). In contrast to a previous study, the results of this one were lower than those of a cross-sectional study conducted in China (87.9\%)(Peng et al., 2020) and India (90\%). (Maheshwari et al., 2020). In reality, students in India had good practice using hand sanitizer, washing their hands often, wearing a mask, and covering a cough and sneeze with a tissue to prevent COVID-19 (Maheshwari et al., 2020).

In this study, 80.2 percent and 64.2 percent of respondents kept social distance and threw used face masks into the trash can, respectively. In research done in India, 83.9 percent of respondents used social distance to prevent COVID-19 (Maheshwari et al., 2020), which was comparable. When it came to the use of face masks, Bule Hora University students were more likely to use them than students at Indian universities. The cause could be due to differences in how laws and regulations are implemented, as well as differences in the institution's COVID-19 pandemic policy for university reopening in Ethiopia. 


\section{Conclusion}

The undergraduate students at Bule Hora University had good knowledge and over half of them had a positive attitude about COVID-19 pandemic prevention and control, according to this survey. They do not, however, have much experience with COVI-19 pandemic prevention. In truth, having good knowledge, attitude, and practice for COVID-19 pandemic prevention and control is extremely important; unfortunately, the students' knowledge, attitude, and practice for COVID-19 pandemic prevention and control fell short of expectations.

\section{Declaration}

\subsection{Ethical approval}

This manuscript has not been published or presented elsewhere in part or in entirety and is not under consideration by another journal. The study was approved by the Research Ethics Committee of college of health and medical science of Bule Hora University, Ethiopia

\subsection{Consent to participate}

Informed consent was obtained from all the individual participants in the study

\subsection{Consent for publication}

All authors have contributed significantly to the work, are aware of this submission, and agree with it.

\subsection{Funding}

This work was funded by Blue Hora University

\subsection{Author contributions}

All authors made substantial contribution in designing the questionnaire, analyzing the data, interpretation of results, reviewing and interpreting the results. The authors reviewed the work critically and agreed to the final approval of the work to be published.

\subsection{Conflict of interest}

There was no conflict of interest in this research work.

\section{Acknowledgment}

First of all, we would like to glorify Almighty God for his daily support. Next, we would like to express our deepest gratitude to the Bule Hora University College of Health and Medicinal Sciences for their funding to do this interesting research. 


\section{Reference}

Asmare, Y., Debre, A. and Orcid, C. A. (2020) 'Assessment of undergraduate student knowledge , practices , and attitude towards COVID-19 in Debre Berhan', pp. 1-14.

Atkure Defar, A. et al. (2020) 'Knowledge, Practice and associated factors towards the Prevention of COVID-19 among high-risk groups: A cross-sectional study in Addis Ababa, Ethiopia', medRxiv, p. 2020.08.14.20172429.

Azlan, A. A. et al. (2020) 'Public knowledge, attitudes and practices towards COVID-19: A cross-sectional study in Malaysia', PLoS ONE, 15(5), pp. 1-15. doi:

10.1371/journal.pone.0233668.

Deress, T. et al. (2018) 'Assessment of Knowledge, Attitude, and Practice about Biomedical Waste Management and Associated Factors among the Healthcare Professionals at Debre Markos Town Healthcare Facilities , Northwest Ethiopia’, 2018.

Dong, Y. et al. (2020) 'Epidemiology of COVID-19 among children in China', Pediatrics, 145(6). doi: 10.1542/peds.2020-0702.

ECA (2020) 'Economic Commission for Africa. COVID-19 in Africa: Protecting Lives and Economies, Ethiopia', (January).

Kumar, J. et al. (2020) 'Knowledge, Attitude, and Practices of Healthcare Workers Regarding the Use of Face Mask to Limit the Spread of the New Coronavirus Disease (COVID-19)', Cureus, 12(4). doi: 10.7759/cureus.7737.

Maheshwari, S. et al. (2020) 'Knowledge, attitude, and practice towards coronavirus disease 2019 (COVID-19) among medical students: A cross-sectional study', Journal of Acute Disease, 9(3), p. 100. doi: 10.4103/2221-6189.283886.

Peng, Y. et al. (2020) 'A cross-sectional survey of knowledge, attitude and practice associated with COVID-19 among undergraduate students in China', BMC Public Health, 20(1), pp. 1-24. doi: 10.1186/s12889-020-09392-z.

Qian, X. et al. (2020) 'Fighting against the common enemy of COVID-19: A practice of building a community with a shared future for mankind', Infectious Diseases of Poverty, 9(1), pp. 4-9. 
doi: 10.1186/s40249-020-00650-1.

Tadesse, A. et al. (2020) 'Knowledge, Attitude, and Practice and Associated Factors towards COVID-19 among College Students in Amhara Region, Ethiopia; A Cross-Sectional Study'. doi: 10.21203/rs.3.rs-38099/v1.

Teferi, S. C. (2020) 'A Review on Knowledge, Attitude, and Practice during the COVID-19 Pandemic in Ethiopia -', 5(2), pp. 40-44.

Walker, P. G. T. et al. (2020) 'Imperial-College-COVID19-Global-Impact-26-03-2020v2.pdf', (March), pp. 1-19.

Wang, D. et al. (2020) 'Clinical Characteristics of 138 Hospitalized Patients with 2019 Novel Coronavirus-Infected Pneumonia in Wuhan, China', JAMA - Journal of the American Medical Association, 323(11), pp. 1061-1069. doi: 10.1001/jama.2020.1585.

WHO (2020a) 'COVID-19 situational update report 32 for the world african region 7 october 2020', pp. 1-9.

WHO (2020b) 'Rights, roles and responsibilities of health workers, including key considerations for occupational safety and health: Interim guidance-2', World Health Organization, (March), pp. $1-2$.

WHO (2020c) 'Situational report of Coronavirus Disease (COVID-19)', Journal of Cardiovascular Nursing, Publish Ah(September). doi: 10.1097/jcn.0000000000000710.

Z, W. and JM, M. (2020) 'Characteristics of and important lessons from the coronavirus disease 2019(COVID-19) outbreak in China', Jama, 2019, p. 10.1001/jama.2020.2648.

Zettler, I. et al. (2020) 'The role of personality in COVID-19 related perceptions, evaluations, and behaviors: Findings across five samples, nine traits, and 17 criteria', (July). 